\title{
Human Lung Tissue and Anaphylaxis
}

\author{
EVIDENCE THAT CYCLIC NUCLEOTIDES MODULATE THE IMMUNOLOGIC \\ RELEASE OF MEDIATORS THROUGH EFFECTS ON MICROTUBULAR ASSEMBLY
}

\author{
MiChaEl KALINER, Allergic Diseases Section, Laboratory of Clinical \\ Investigation, National Institute of Allergy and Infectious Diseases, \\ National Institutes of Health, Bethesda, Maryland 20014
}

A B S T R A C T The addition of specific antigen to IgEsensitized human lung tissue causes the secretion of the mediators histamine and slow-reacting substance of anaphylaxis. The mechanisms by which increased levels of cyclic AMP suppress and increased levels of cyclic GMP enhance this secretory process were studied. Colchicine, an agent which disrupts many secretory reactions by binding to microtubules in their disassembled $6 \mathrm{~S}$ form, was a relatively ineffective inhibitor of the antigen-induced release of mediators unless lung fragments were incubated at $4^{\circ} \mathrm{C}$ for $60 \mathrm{~min}$ to induce microtubular disassembly. As colchicine appeared to inhibit the immunologic secretion of mediators from human lung tissue most effectively after microtubular disassembly, the capacity of colchicine to modulate the release reaction indicated the state of microtubular assembly; inhibition by colchicine signaled a shift to the colchicine-sensitive $6 \mathrm{~S}$ subunits whereas failure to inhibit suggested maintenance in the colchicine-resistant polymerized state.

Exogenously added 8-Bromo-cyclic GMP prevented low temperature-facilitated colchicine suppression of mediator release suggesting that increased levels of cyclic GMP stabilize polymerized microtubules. Transiently increased cyclic AMP concentrations, either exogenously added as 8-Bromo-cyclic AMP or endogenously produced by isoproterenol, promoted colchicine suppression of mediator release suggesting that microtubular disassembly was produced. Direct measurement of cyclic AMP levels revealed parallel kinetics after isoproterenol stimulation between control and colchicine-treated lung fragments.

The requirement for functional microtubules in the release reaction may occur after the antigen IgEstimulated activation of a serine esterase, energy

Received for publication 22 December 1976 and in revised form 25 May 1977. utilization, and an intracellular calcium requirement. The mechanism by which cyclic nucleotides influence microtubular assembly is postulated to involve the degree of phosphorylation-dephosphorylation of microtubules.

\section{INTRODUCTION}

The union of specific antigen with tissue-bound IgE antibody in human lung tissue initiates a partially elucidated sequence of events: the extracellular calcium requiring conversion of a serine esterase from its precursor to activated form, an energy requirement, a second calcium requirement, and a cyclic adenosine 3',5'-monophosphate (cyclic AMP)-inhibitable step followed by the release of histamine and slow-reacting substance of anaphylaxis (SRS-A) ${ }^{1}$ (1). These biochemical events translate the immunologic signal at the surface of the lung mast cell to the intracellular process of moving the mediator containing secretory granules toward the cell surface where sequential exocytosis (2) occurs. Functioning microtubules have been shown to be necessary for many secretory processes (3-5) including the nonimmunologic release of histamine from human peripheral leukocytes $(7,8)$ and human lung tissue (9). It seemed possible, therefore, that a portion of the partially delineated biochemical sequence of events involved in the immunologic release process might relate to the assembly and function of microtubules.

In contrast to most other secretory systems (10), increased intracellular concentrations of cyclic AMP inhibit the immunologic secretion of mediators from human lung tissue (11), polypoid nasal mucosa (12), and blood basophils (13). Indeed, cyclic AMP exerts a general inhibitory influence upon diverse immuno-

\footnotetext{
${ }^{1}$ Abbreviation used in this paper: SRS-A, slow-reacting substance of anaphylaxis.
} 
logic effector systems $(14,15)$. Increases in cyclic guanosine 3',5'-monophosphate (cyclic GMP) enhance the antigen-initiated secretion of mediators from lung tissue $(16,17)$ and nasal mucosa $(12)$, and may partially prevent the inhibitory effects of cyclic AMP (18). The site of action of these cyclic nucleotides in modulating the secretion of mediators remains unclear although in other systems there are well-described morphologic (19-22) and biochemical (23-26) interactions between cyclic AMP and microtubules. These data suggest the possibility that the concentration of cyclic nucleotides in human lung mast cells might influence the immunologic release reaction through effects on microtubules.

The data reported herein confirms the requirement for functional microtubules in mediator release (6-9) as indicated by the inhibitory action of colchicine under defined conditions. Furthermore, data are presented which suggests that cyclic AMP and GMP exert their modulating effects on the secretion of mediators from human lung by influencing the state of microtubular assembly.

\section{METHODS}

D,L-Isoproterenol hydrochloride, colchicine, vinblastine sulfate and podophylline (Sigma Chemical Co., St. Louis, Mo.); disodium and tetrasodium EDTA (Fisher Scientific Co., Pittsburgh, Pa.); 8-Bromo-cyclic AMP and 8-Bromo-cyclic GMP (Boehringer Mannheim Biochemicals, Indianapolis, Ind.) were obtained from the manufacturers. Lumicolchicine was prepared by a modification of the method of Wilson and Friedkin (27). An aqueous preparation of $10 \mathrm{mM}$ colchicine was exposed to sunlight for 3 days and conversion of colchicine to lumicolchicine determined by disappearance of absorbance at $350 \mathrm{~nm}$, and appearance of absorbant peaks at 305 and $255 \mathrm{~nm}$.

Preparation of human lung tissue for the antigen-induced release of mediators. Human lung tissue obtained at the time of resection, generally for cancer or bronchiectasis, was prepared for the antigen-induced release of histamine and SRS-A as previously described (17). Only macroscopically normal areas of lung tissue were studied. The peripheral, tumor-free areas were dissected free of pleura, large bronchi (>3-5 $\mathrm{mm}$ ) and blood vessels, fragmented into $200-\mathrm{mg}$ replicates, washed extensively with Tyrode's buffer, and incubated in undiluted serum from a patient allergic to ragweed (FP.) for either $2 \mathrm{~h}$ at $37^{\circ} \mathrm{C}$ or $18 \mathrm{~h}$ at room temperature. The sensitized fragments were washed and placed in $3 \mathrm{ml}$ of Tyrode's buffer at $37^{\circ} \mathrm{C}$. Agents under study were dissolved in Tyrode's buffer immediately before use and then they were added in 10- $\mu$ l aliquots to the lung fragments. After the appropriate incubation period (in Results), $0.5 \mu \mathrm{g} / \mathrm{ml}$ ragweed antigen E (Research Resources Branch, National Institute of Allergy and Infectious Diseases, Bethesda, Md.) was added and the incubation continued for $30 \mathrm{~min}$ to permit mediator release. The histamine and SRS-A secreted were quantitated by bioassay on the isolated, atropinized guinea pig ileum as described (28). Residual tissue histamine was extracted from the lung fragments by boiling for $8 \mathrm{~min}$. Colchicine, vinblastine, and podophylline were found to inhibit the guinea pig ileum's contractions and were therefore removed from the lung fragments after an initial incubation (priming) period by washing twice in Tyrode's buffer. None of the other agents interfered with the bioassay and no agent induced the nonspecific release of mediators in the absence of antigen challenge.

The concentration of histamine and SRS-A released from the IgE-sensitized tissues by antigen challenge in the absence of any drugs was considered as control release and taken as representing $100 \%$. The percent inhibition or enhancement of the release of mediators secondary to the effects of any agent was calculated on that basis. Histamine and SRS-A were determined in duplicate samples and the values expressed represent the mean. The variation between duplicate samples averaged $<5 \%$. Each experiment was repeated two or more times and the data presented herein is representative.

Preparation of human lung tissue for the determination of cyclic AMP content. Replicate fragments of human lung tissue were incubated in undiluted, nonallergic serum for $2 \mathrm{~h}$ at $37^{\circ} \mathrm{C}$ in parallel with those samples to be employed for mediator release (17). The fragments were washed free of serum, placed in $3 \mathrm{ml}$ Tyrode's buffer at $37^{\circ} \mathrm{C}$, and processed in parallel with the sensitized replicates. After the experimental manipulations and at the time the IgE-sensitized fragments were receiving antigen $\mathrm{E}$, these samples were transferred to $1 \mathrm{ml}$ ice-cold $10 \%$ perchloric acid. The cyclic AMP was extracted by homogenization for $30 \mathrm{~s}$ at $\mathbf{4 , 0 0 0 ~} \mathrm{rpm}$ (Polytron homogenizer, Brinkmann Instruments, Inc., Westbury, N.Y.) followed by centrifugation for $15 \mathrm{~min}$ at $200 \mathrm{~g}$. The precipitate was retained and digested with $2 \mathrm{ml} 0.1 \mathrm{~N} \mathrm{NaOH}$ for 48-72 $\mathrm{h}$ for protein determination (29) and the supernate was neutralized with $0.35 \mathrm{ml} 5 \mathrm{~N} \mathrm{KOH}$. After centrifugation (15 min, $200 \mathrm{~g}$ ), the supernate was applied to $1.5 \times 0.7-\mathrm{cm}$ columns of AG $1 \times 8,200-400$ mesh, formate form (Bio-Rad Laboratories, Richmond, Calif.) equilibrated in $0.1 \mathrm{~N}$ formic acid. The columns were washed with $10 \mathrm{ml} 0.1 \mathrm{~N}$ formic acid and the cyclic AMP eluted with $10 \mathrm{ml} 1 \mathrm{~N}$ formic acid. The eluates were evaporated to dryness under negative pressure (Rotary Evapomix, Buchler Instruments Div., Searle Analytic Inc., Fort Lee, N. J.). The dried eluates were resuspended in $1.0 \mathrm{ml}$ sodium acetate buffer $(50 \mathrm{mM}, \mathrm{pH} 4.0)$ and the cyclic AMP content determined by the protein binding assay (30) as described (16). Recovery of cyclic AMP was monitored by cyclic $\left.{ }^{14} \mathrm{C}\right] \mathrm{AMP}$ added to the perchloric acid and was $75-90 \%$. Representative samples were treated with cyclic nucleotide phosphodiesterase and $95 \%$ or more of the assayable cyclic AMP was removed. The $2.8 \mathrm{pmol} \mathrm{cy}-$ clic AMP/mg protein determined in the experiment presented is at the same level of cyclic AMP as previously determined in 18 human lungs (17).

\section{RESULTS}

Development of an experimental model to detect the state of assembly of microtubules. Although colchicine has been reported to impede secretory reactions in several tissues (3-9), it was initially difficult to reproduce these findings. Incubation of sensitized lung fragments under varied conditions in eight initial experiments with colchicine $(0.0001-1 \mathrm{mM})$, and one experiment with vinblastine $(0.01 \mathrm{mM})$ and podophylline $(1 \mu \mathrm{g} / \mathrm{ml})$ resulted in minimal suppression of the immunologic release of histamine and no inhibition of SRS-A release (Table I). In total, 17 lung specimens had been treated with colchicine $(0.1-1 \mathrm{mM})$ for 60-120 min before antigen challenge and the mean 
TABLE I

The Effect of Colchicine on the Immunologic Release of Histamine and SRS-A from Human Lung Tissue

\begin{tabular}{|c|c|c|c|c|c|}
\hline \multirow[b]{2}{*}{ Exp } & \multirow[b]{2}{*}{$\begin{array}{l}\text { Colchi- } \\
\text { cine }\end{array}$} & \multicolumn{2}{|c|}{ Histamine release } & \multicolumn{2}{|c|}{ SRS-A release } \\
\hline & & $\begin{array}{l}\% \text { Re- } \\
\text { leased }\end{array}$ & $\begin{array}{l}\text { \% Control } \\
\text { release }\end{array}$ & Release & $\begin{array}{c}\% \text { Control } \\
\text { release }\end{array}$ \\
\hline & $m M$ & & & $U / g$ & \\
\hline$A^{*}$ & 1.0 & 29.0 & 95 & 3,000 & 100 \\
\hline B & 1.0 & 9.0 & 77 & 250 & 100 \\
\hline C & 1.0 & 33.0 & 104 & Not done & \\
\hline D & 0.5 & 19.0 & 83 & 1,500 & 100 \\
\hline $\mathbf{E}$ & 0.5 & 14.5 & 64 & 1,500 & 100 \\
\hline $\mathbf{F}$ & 0.1 & 30.5 & 89 & 1,250 & 83 \\
\hline G & 0.1 & 30.5 & 89 & 4,500 & 100 \\
\hline $\mathrm{H} \ddagger$ & 0.1 & 15.0 & 117 & 625 & 83 \\
\hline
\end{tabular}

* Lung fragments were incubated with cholchicine for the following periods at $37^{\circ} \mathrm{C}$ : $\operatorname{Exp~A,~} 160 \mathrm{~min}$; $\operatorname{Exp~B}, 30 \mathrm{~min}$; Exp C, 60 min; Exp D, 60 min; Exp E, 80 min; Exp F, 120 min; Exp G, 45 min; and Exp H, 30 min.

I In this experiment, vinblastine $(0.01-10 \mu \mathrm{M})$ and podophylline $(1-0.01 \mu \mathrm{g} / \mathrm{ml})$ also failed to significantly effect the release of histamine and SRS-A.

inhibition of histamine release has been $21 \pm 4 \%$ $(P=<0.01)$ and SRS-A release has been $8.6 \pm 6 \%$.

Microtubules are thought to exist in a dynamic equilibrium with their disassembled form, called tubulin (31). As disassembly of polymerized microtubules is known to be favored by cold temperatures (32) and was observed to augment the inhibition of histamine from human leukocytes by colchicine $(7,8)$, the effects of cold temperature on colchicine inhibition of mediator release from human lung tissue was examined (Fig. 1). Lung fragments were colchicineprimed by incubation in 0.01-500 $\mu \mathrm{M}$ colchidine for $120 \mathrm{~min}$ and then washed twice. Half the colchicineprimed fragments were kept at $37^{\circ} \mathrm{C}$ while the other half were incubated in an ice bath at $4^{\circ} \mathrm{C}$ for $60 \mathrm{~min}$ followed by an additional $30-\mathrm{min}$ incubation at $37^{\circ} \mathrm{C}$. Antigen challenge of the fragments which had been maintained at $37^{\circ} \mathrm{C}$ induced the same amount of histamine and SRS-A release as was released by control samples kept either at $4^{\circ}$ or $37^{\circ} \mathrm{C}$ (Fig. 1). In contrast, those fragments which were incubated at $4^{\circ} \mathrm{C}$ had marked suppression of mediator release confirming that colchicine can indeed inhibit the immunologic release of mediators but is most effective after a putative disassembly of microtubules as occurs with cold temperatures. Vinblastine $(50 \mu \mathrm{M})$ similarly suppressed the immunologic release of histamine and SRSA but only after a 60 -min incubation at $4^{\circ} \mathrm{C}$. By contrast, lumicolchicine $(1.0-0.1 \mathrm{mM})$ remained ineffective even after cold treatment.

Subsequent analysis revealed that a minimum of 60 min incubation at $4^{\circ} \mathrm{C}$ was optimal in order to in-

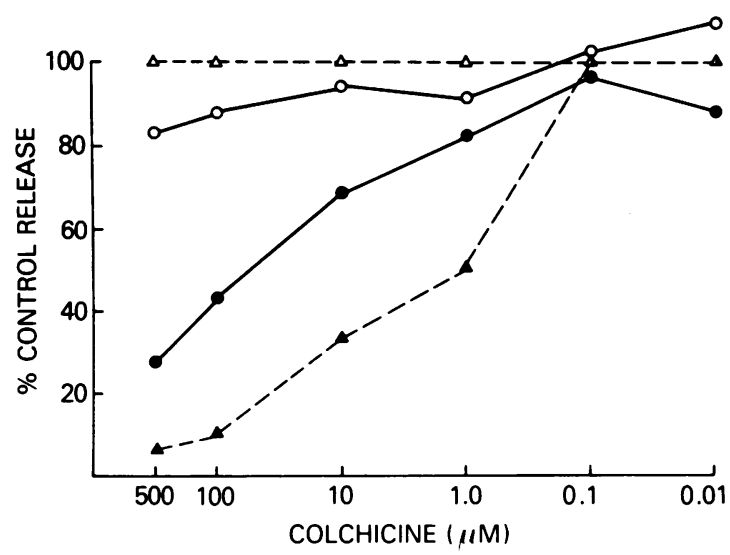

FIGURE 1 The effect of cold temperature on the capacity of colchicine to suppress the immunologic release of histamine and SRS-A from human lung tissue. Lung fragments were incubated with $0.01-0.5 \mu \mathrm{M}$ colchicine for $2 \mathrm{~h}$ at $37^{\circ} \mathrm{C}$ and washed twice. One-half the fragments were kept at $37^{\circ} \mathrm{C}$ while the other half were incubated for $60 \mathrm{~min}$ at $4^{\circ} \mathrm{C}$ followed by $30 \mathrm{~min}$ at $37^{\circ} \mathrm{C}$ before all the fragments were simultaneously challenged with antigen. Histamine release (O), SRS-A release $(\triangle)$ from fragments not exposed to $4^{\circ} \mathrm{C}$ incubation; histamine release $(\Theta)$, SRS-A release $(\Delta)$ from fragments exposed to $4^{\circ} \mathrm{C}$. Histamine release from control tissue kept either at $37^{\circ} \mathrm{C}$ or exposed to $4^{\circ} \mathrm{C}$ for $60 \mathrm{~min}$ but never exposed to colchicine was $23 \%$ and SRS-A release $1,500 \mathrm{U} / \mathrm{g}$.

duce microtubular disassembly and to facilitate the capacity of colchicine to suppress mediator release (Table II). Furthermore, even after a $60 \mathrm{~min}$ incubation at $4^{\circ} \mathrm{C}$, the ability of colchicine to bind to the disassembled microtubules and to suppress the im-

\section{TABLE II}

The Effect of Varying the Incubation Time at $4^{\circ} \mathrm{C}$ on the Capacity of Colchicine to Suppress the Immunologic Release of Histamine and SRS-A from Human Lung Tissue*

\begin{tabular}{ccc}
\hline & \multicolumn{2}{c}{$\%$ Control } \\
\cline { 2 - 3 } Incubation at $4^{\circ} \mathrm{C}$ & Histamine release & SRS-A release \\
\hline $\min$ & $100 \ddagger$ & $100 \S$ \\
0 & 80 & 90 \\
2 & 54 & 34 \\
30 & 24 & 10 \\
60 & 28 & 18 \\
90 & $23^{\prime \prime}$ & $18^{\prime \prime}$ \\
120 & &
\end{tabular}

* Lung fragments were incubated with $0.1 \mathrm{mM}$ colchicine for $80 \mathrm{~min}$ at $37^{\circ} \mathrm{C}$, washed twice, incubated at $4^{\circ} \mathrm{C}$ for varying times and then incubated for $30 \mathrm{~min}$ at $37^{\circ} \mathrm{C}$ before antigen challenge.

f Control histamine release was $38 \%$.

$\$$ Control SRS-A release was $2,750 \mathrm{U} / \mathrm{g}$.

" Histamine release from tissue incubated at $4^{\circ} \mathrm{C}$ for $120 \mathrm{~min}$ but never exposed to colchicine was $38 \%$; SRS-A release was $2,750 \mathrm{U} / \mathrm{g}$. 
munologically activated reaction required an additional 30 -min incubation at $37^{\circ} \mathrm{C}$ (Table III).

On the basis of these observations, the following experimental design was employed and consistently resulted in colchicine-induced suppression of mediator release. After sensitization, the fragments were incubated with $0.1 \mathrm{mM}$ colchicine for 60 to $120 \mathrm{~min}$ at $37^{\circ} \mathrm{C}$ (colchicine priming), the tissue was washed twice and incubated for $60 \mathrm{~min}$ at $4^{\circ} \mathrm{C}$ (microtubule disassembly). The chilled, colchicine-primed fragments were incubated for $30 \mathrm{~min}$ at $37^{\circ} \mathrm{C}$ (colchicine-microtubule binding), antigen $\mathrm{E}$ was added, and then the incubation was continued for $30 \mathrm{~min}$. Under these conditions, colchicine-induced inhibition was interpreted as indicating a state of microtubular disassembly whereas the failure to inhibit signified that the microtubules remained in their polymerized state.

The effects of cyclic GMP on the state of microtubule assembly. Increased intracellular cyclic GMP in human lung tissue which occurs after adding exogenous cyclic GMP (16) and after addition of cholinergic agonists or prostaglandin $F_{2 \alpha}(16,17)$ is associated with marked augmentation of the antigen-induced secretory reaction. The possibility that the effect of increased levels of cyclic GMP might be generated by an interaction with microtubules was explored. Incubation of lung fragments with 0.01-10 $\mu \mathrm{M}$ 8-Bromocyclic GMP for $15 \mathrm{~min}$ before antigen challenge produced an enhancement of mediator release. The peak response was appreciated at $1.0 \mu \mathrm{M}$ with an increase in histamine release from 36 to $47 \%$ (a $30 \%$ enhancement) and doubling of SRS-A release from 1,500 to $3,000 \mathrm{U} / \mathrm{g}$.

\section{TABLE III}

The Effect of Varying the Incubation Time at $37^{\circ} \mathrm{C}$ on the Capacity of Colchicine to Suppress the Immunologic Release of Histamine and SRS-A from Human Lung Tissue Which Has Previously Been Incubated at $4^{\circ} \mathrm{C} *$

\begin{tabular}{ccc}
\hline & \multicolumn{2}{c}{$\%$ Control } \\
\cline { 2 - 3 } Incubation at $37^{\circ} \mathrm{C}$ & Histamine release & SRS-A release \\
\hline $\min$ & $100 \ddagger$ & \\
0 & 85 & $100 \$$ \\
2 & 64 & 100 \\
10 & 18 & 50 \\
20 & 14 & 18 \\
30 & 14 & 9 \\
60 & & 9 \\
\hline
\end{tabular}

* Lung fragments were incubated with $0.1 \mathrm{mM}$ colchicine for $120 \mathrm{~min}$ at $37^{\circ} \mathrm{C}$, washed twice, incubated for $60 \mathrm{~min}$ at $4^{\circ} \mathrm{C}$ and then incubated at $37^{\circ} \mathrm{C}$ for varying periods of time before antigen challenge.

\$ Control histamine release was $\mathbf{1 7 . 0 \%}$.

$\S$ Control SRS-A release was $1,500 \mathrm{U} / \mathrm{g}$.
Colchicine-primed $\left(0.1 \mathrm{mM}, 120 \mathrm{~min}, 37^{\circ} \mathrm{C}\right)$ lung fragments were incubated with either buffer or $1 \mu \mathrm{M}$ 8-Bromo-cyclic GMP for $15 \mathrm{~min}$ at $37^{\circ} \mathrm{C}$ and then both sets of fragments were chilled to $4^{\circ} \mathrm{C}$ for 30 to $120 \mathrm{~min}$. The chilled fragments were washed twice, incubated for $30 \mathrm{~min}$ at $37^{\circ} \mathrm{C}$, and challenged with antigen (Table IV). The colchicine-primed fragments which were incubated with 8-Bromo-cyclic GMP before chilling demonstrated little decrease in mediator release whereas those fragments never encountering 8-Bromocyclic GMP developed a time-dependent, coldinduced, progressive impairment of mediator release. These data suggests, therefore, that increased levels of cyclic GMP may prevent cold-induced microtubular disassembly and by inference favor maintenance of microtubules in their polymerized state.

The effects of cyclic AMP on the state of microbular assembly. The possibility that cyclic AMP disrupts the immunologic secretion of mediators through effects on the state of microtubular assembly was then examined. Lung fragments were incubated with $1 \mathrm{mM}$ 8-Bromo-cyclic AMP for $15 \mathrm{~min}$, washed twice, and then challenged with antigen $5,15,30$, and $60 \mathrm{~min}$ later (Fig. 2). The inhibitory effects of 8-Bromo-cyclic AMP on the secretion of mediators persisted for 5-15

\section{TABLE IV}

The Effects of 8-Bromo-cyclic GMP upon the Capacity for Cold Temperature to Induce Microtubular Disassembly*

\begin{tabular}{ccccc}
\hline Colchicine & $\begin{array}{c}\text { 8-Bromo- } \\
\text { cyclic GMP }\end{array}$ & $\begin{array}{c}\text { Incubation } \\
\text { at } \mathbf{4}^{\circ} \mathrm{C}\end{array}$ & $\begin{array}{c}\text { Histamine } \\
\text { release }\end{array}$ & SRS-A release \\
\hline & & $\min$ & $\%$ & U/g \\
- & - & 120 & 34.5 & 1,500 \\
- & $+\neq$ & 120 & 31.5 & 1,250 \\
+ & - & - & 30.5 & 1,250 \\
+ & - & 30 & 18.5 & 500 \\
+ & + & 30 & 35.5 & 1,000 \\
+ & - & 60 & 8.5 & 150 \\
+ & + & 60 & 27.5 & 1,000 \\
+ & - & 90 & 11.0 & 250 \\
+ & + & 90 & 25.5 & 950 \\
+ & - & 120 & 12.5 & 250 \\
+ & + & 120 & 33.5 & 1,125 \\
\hline
\end{tabular}

* Lung fragments were incubated with $0.1 \mathrm{mM}$ colchicine for $2 \mathrm{~h}$ at $37^{\circ} \mathrm{C}$ and washed twice. Half the fragments were incubated for $15 \mathrm{~min}$ with $1 \mu \mathrm{M}$ 8-Bromo-cyclic GMP. All the fragments were then incubated at $4^{\circ} \mathrm{C}$ for $30-120 \mathrm{~min}$, washed twice and incubated at $37^{\circ} \mathrm{C}$ for $30 \mathrm{~min}$ before antigen challenge.

‡ The 8-Bromo-cyclic GMP was removed by washing twice after incubation at $4^{\circ} \mathrm{C}$. Replicate fragments challenged with antigen in the presence of 8-Bromo-cyclic GMP released $47 \%$ of their histamine content and 3,000 U SRS-A/g. 


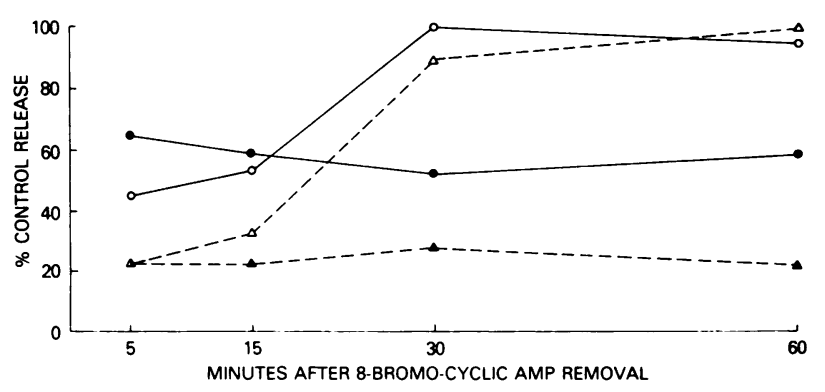

FIGURE 2 The effect of 8-Bromo-cyclic AMP on the capacity of colchicine to suppress the immunologic release of histamine and SRS-A from human lung tissue. Untreated lung fragments and colchicine-primed lung fragments $(0.1 \mathrm{mM}, 75$ min, $37^{\circ} \mathrm{C}$ ) were incubated with $1 \mathrm{mM} \mathrm{8-Bromo-cyclic} \mathrm{AMP}$ for $15 \mathrm{~min}$, washed twice, and then this antigen was challenged 5 to $60 \mathrm{~min}$ later. Histamine release (O), SRS-A release $(\Delta)$ from fragments exposed only to 8-Bromo-cyclic AMP; histamine release $(\Theta)$, SRS-A release $(\Delta)$ from colchicine-primed fragments after exposure to 8-Bromo-cyclic AMP. Histamine release from control tissue never exposed to either agent was $34.5 \%$ and SRS-A release was $4,500 \mathrm{U} / \mathrm{g}$; histamine release from colchicine-primed fragments never exposed to 8-Bromo-cyclic AMP was $30.5 \%$ and SRS-A release was 4,500 $\mathrm{U} / \mathrm{g}$.

min after its removal with the release of both histamine and SRS-A returning to control levels by $30 \mathrm{~min}$. In contrast, antigen-induced mediator release from fragments which had been colchicine primed $(0.1 \mathrm{mM}$, $75 \mathrm{~min}, 37^{\circ} \mathrm{C}$ ) before incubation with 8-Bromo-cyclic AMP remained suppressed $60 \mathrm{~min}$ after removal of 8Bromo-cyclic AMP. These data suggest the possibility that increased levels of cyclic AMP may have facilitated the inhibitory action of colchicine by inducing microtubular disaggregation.

The ability of endogenously produced cyclic AMP which occurs after beta adrenergic stimulation of human lung tissue (33) to reproduce the same effects as exogenously added cyclic AMP was studied. Isoproterenol produces a rapid rise in cyclic AMP in human lung which dissipates promptly after its removal, leaving lung tissue which is capable of the uninhibited release of mediators (11). Lung fragments were incubated with $1 \mu \mathrm{M}$ isoproterenol for $3 \mathrm{~min}$, washed twice, and then challenged with antigen $10 \mathrm{~s}$ -60 min later (Fig. 3). The immunologic release of histamine and SRS-A was totally suppressed for the initial $15 \mathrm{~min}$ after removal of isoproterenol, SRS-A release returned to control levels by $25 \mathrm{~min}$ and histamine release gradually recovered through $60 \mathrm{~min}$. Colchicine-primed $\left(0.1 \mathrm{mM}, 60 \mathrm{~min}, 37^{\circ} \mathrm{C}\right)$ replicates remained totally suppressed $60 \mathrm{~min}$ after isoproterenol removal.

Although colchicine is not known to have an effect on cyclic nucleotide phosphodiesterase, the possibility that colchicine might interfere with cyclic AMP catabolism was studied. Lung fragments were treated with

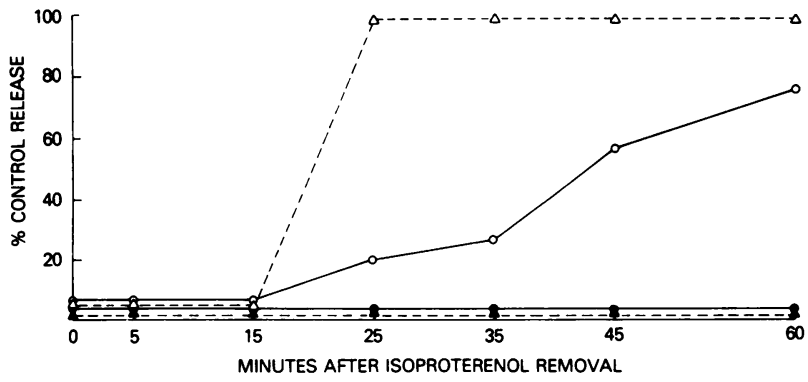

FIGURE 3 The effect of isoproterenol on the capacity of colchicine to suppress the immunologic release of histamine and SRS-A from human lung tissue. Untreated lung fragments and colchicine-primed lung fragments $\left(0.1 \mathrm{mM}, 60 \mathrm{~min}, 37^{\circ} \mathrm{C}\right)$ were incubated with $1 \mu \mathrm{M}$ isoproterenol for $3 \mathrm{~min}$, washed twice, and the antigen challenged $10 \mathrm{~s}$ to $60 \mathrm{~min}$ later. Histamine $(O)$, SRS-A release $(\triangle)$ from fragments exposed only to isoproterenol; histamine release (O), SRS-A release $(\Delta)$ from colchicine-primed fragments exposed to isoproterenol. Histamine release from control tissue never exposed to either agent was $7.7 \%$ and SRS-A release $250 \mathrm{U} / \mathrm{g}$; histamine release from colchicine-primed fragments never exposed to isoproterenol ws $5 \%$ and SRS-A release $250 \mathrm{U} / \mathrm{g}$.

$1 \mu \mathrm{M}$ isoproterenol for $3 \mathrm{~min}$, washed twice, and then either challenged with antigen or transferred to $10 \%$ perchloric acid from $10 \mathrm{~s}$ to $90 \mathrm{~min}$ later (Fig. 4). Isoproterenol treatment caused a prompt increase in cyclic AMP levels from $2.8 \pm 0.5$ to $23.2 \pm 3 \mathrm{pmol} / \mathrm{mg}$ protein which returned to base-line levels $30 \mathrm{~min}$ after washing. The inhibition of the immunologic release of histamine by isoproterenol was reversed $30 \mathrm{~min}$ afte its removal whereas SRS-A release required $90 \mathrm{~min}$ before returning to control release levels. Colchicineprimed replicates $\left(0.1 \mathrm{mM}, 60 \mathrm{~min}, 37^{\circ} \mathrm{C}\right)$ had identical cyclic AMP responses (base-line level of $2.5 \pm 0.15$ $\mathrm{pmol} / \mathrm{mg}$ protein, maximal increase to $18.3 \pm 0.2 \mathrm{pmol} /$ $\mathrm{mg}$ protein and return to base-line values by $30 \mathrm{~min}$ after isoproterenol removal) but the immunologic release of both histamine and SRS-A remained suppressed $90 \mathrm{~min}$ after isoproterenol removal. These data supports the possibility that increased concentrations of cyclic AMP are associated with microtubular disassembly thereby facilitating colchicine suppression of the antigen-induced release of mediators.

Relationship between EDTA treatment of lung tissue and the state of microtubular assembly. The intracellular events involved in the antigen-initiated release of mediators includes a late $\mathrm{Ca}^{++}$-requiring, EDTA-inhibitable step followed by the cyclic nucleotide modulatable stage (1). It was therefore of interest to determine the relationship of intracellular $\mathrm{Ca}^{++}$and microtubular assembly. Both colchicineprimed lung fragments $\left(0.1 \mathrm{mM}, 80 \mathrm{~min}, 37^{\circ} \mathrm{C}\right)$ and replicates never exposed to colchicine were incubated in $5 \mathrm{mM}$ EDTA (disodium and tetrasodium EDTA, $1: 1$ by volume, $\mathrm{pH} 7.5$ ) in calcium and magnesiumfree Tyrode's buffer for 5 or $15 \mathrm{~min}$, washed twice, 

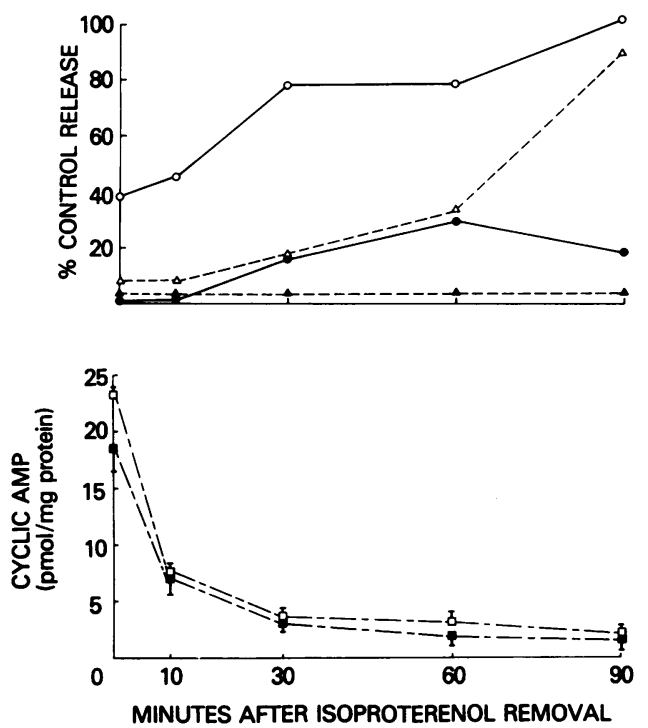

FIGURE 4 The effect of isoproterenol on the capacity of colchicine to suppress the immunologic release of histamine and SRS-A from human lung tissue with concomitant measurement of cyclic AMP levels. The same protocol as was employed for Fig. 3 except that replicate lung fragments were transferred to $10 \%$ perchloric acid at the time of antigen challenge and assayed for cyclic AMP content. Histamine release $(O)$, SRS-A release $(\Delta)$, cyclic AMP levels $(\square)$ in fragments exposed to isoproterenol only; histamine release (O), SRS-A release $(\boldsymbol{\Delta})$, cyclic AMP levels $(\square)$ in colchicine-primed fragments $\left(0.1 \mathrm{mM}, 60 \mathrm{~min}, 37^{\circ} \mathrm{C}\right)$ exposed to isoproterenol. Histamine release from control tissue never exposed to either agent was $6 \%$, SRS-A release was $1,875 \mathrm{U} / \mathrm{g}$, and cyclic AMP was $2.8 \pm 0.5 \mathrm{pmol} / \mathrm{mg}$ protein; histamine release from colchicineprimed lung fragments never exposed to isoproterenol was $5.5 \%$, SRS-A was $1,875 \mathrm{U} / \mathrm{g}$, and cyclic AMP was $2.5 \pm 0.15$ $\mathrm{pmol} / \mathrm{mg}$ protein.

incubated in Tyrode's buffer containing calcium and magnesium for $30 \mathrm{~min}$ and challenged with antigen (Table V). Prior treatment with EDTA was not found to facilitate colchicine inhibition of mediator release; indeed, slight augmentation of release was found.

\section{DISCUSSION}

The data presented herein suggest that cyclic nucleotides modulate the immunologic release of histamine and SRS-A from IgE-sensitized human lung tissue by influencing the state of assembly of microtubules; cyclic AMP appears to induce disassembly thereby suppressing mediator release whereas cyclic GMP favors microtubular polymerization in association with enhancement of the secretory reaction. Microtubules exist in two states; a polymerized functional form and various states of disassembly down to a $6 \mathrm{~S}$ globular form called tubulin (31). The stability of microtubules in maintaining their polymerized state varies with the cell type involved: microtubules from cells in mitosis
TABLE V

Effects of EDTA on the Capacity of Colchicine to Suppress the Immunologic Release of Histamine and SRS-A from Human Lung Tissue*

\begin{tabular}{cccc}
\hline Colchicine & EDTA & Histamine release & SRS-A release \\
\hline & $\min$ & $\%$ & Ulg \\
- & - & 9 & 750 \\
- & 5 & 11 & 1,500 \\
- & 15 & 20 & 1,875 \\
+ & - & 8 & 750 \\
+ & 5 & 11 & 750 \\
+ & 15 & 18 & 1,125 \\
\hline
\end{tabular}

* Untreated or colchicine-primed $\left(0.1 \mathrm{mM}, 80 \mathrm{~min}, 37^{\circ} \mathrm{C}\right)$ lung fragments were incubated in calcium-magnesium-free Tyrode's buffer containing $5 \mathrm{mM}$ EDTA for 5 or $15 \mathrm{~min}$, washed twice in normal Tyrode's buffer, incubated for 30 min at $37^{\circ} \mathrm{C}$ and challenged with antigen.

are quite labile, those from axons and dendrites are intermediate and ciliary and flagellar microtubules are quite stable (34). Colchicine and the vinblastine alkaloids bind disaggregated tubulin in soluble pools thereby preventing their ability to reassemble and shifting the equilibrium towards the disassembled state. Indeed, it appears that colchicine may fail to bind to or effect intact, polymerized microtubules (34). Judging from the relative ineffectiveness of colchicine as an inhibitor of the immunologically initiated secretion of mediators from human lung, one would conclude that the polymerized microtubules in mast cells in human lung tissue are relatively stable. It is only after treatment of lung tissue with low temperatures, which is known to promote disassembly of microtubules (32), that the role of microtubules in mediator release from human lung becomes clear.

Colchicine, as well as other microtubule-active agents, may have multiple inhibitory effects on cell functions other than through microtubule disassembly (34). Several lines of evidence suggest that the inhibitory actions of colchicine on the immunologic release of mediators from human lung tissue after cold treatment are through effects on microtubules: the inhibition is also produced by vinblastine, the colchicine isomer lumicolchicine is ineffective and direct morphologic evaluation of purified rat mast cells after colchicine treatment reveals an absence of recognizable microtubules (35). Furthermore, the binding constant for colchicine to chick embryo brain tubulin is $2 \times 10^{6}$ liters $/ \mathrm{mol}$ at $37^{\circ} \mathrm{C}$ indicating that $50 \%$ of the binding sites would be saturated at $0.5 \mu \mathrm{M}(36)$. The inhibitory dose response of colchicine on mediator release from human lung tissue after cold temperature treatment approaches this theoretical level but remains much less sensitive to colchicine as compared with 
processes (such as mitosis in HeLa cells) which are disrupted by $1 \mathrm{pM}$ colchicine (37).

Once the necessity for intact, polymerized microtubules in the immunologic release of mediators was recognized, it was possible to interpret the capacity of colchicine to influence the immunologic secretory process as reflective of the state of assembly of microtubules: colchicine-primed tissue which after antigen challenge released amounts of mediators equal to control replicates indicated that the microtubules were in the polyermized state whereas inhibition of mediator release was indicative of disassembly of microtubules and binding by colchicine.

Increased levels of cyclic GMP which have been observed in human lung tissue after cholinergic stimulation and $\mathrm{PGF}_{2 \alpha}$ incubation $(16,17)$ were found to prevent cold-induced microtubular disassembly. By inference, increased levels of cyclic GMP favor the polymerized state of microtubular assembly and thereby may facilitate the immunologically induced movement of secretory granules along an increased microtubular framework. An association between cyclic GMP and increased numbers of microtubules has been noted in human polymorphonuclear leukocytes (38) and may account for the augmentation of lysosomal enzyme release noted under certain experimental conditions (39) with this cell type as well as correction of the in vitro defects seen in leukocytes from Chediak-Higashi patients $(38,40)$.

Conversely, colchicine suppression of mediator release was facilitated by transiently increased levels of cyclic AMP either exogenously added or endogenously produced, suggesting that one of the actions of cyclic AMP results in microtubular disassembly much the same as cold temperature. These effects were seen after treatment of sensitized lung fragments with 8-Bromocyclic AMP or isoproterenol and could not be attributed to an alteration in cyclic AMP catabolism by colchicine as direct measurement of cyclic AMP levels revealed equivalent responses between colchicineprimed and control fragments. The cyclic AMP levels measured after isoproterenol stimulation reflect the entire population of cells in intact lung fragments while the immunologic release of histamine and SRS-A involves only the small subpopulation of mast cells. Colchicine treatment of lymphocytes has been found to augment a late phase of concanavalin A- or phytohemogglutinin-induced increases in cyclic AMP but not to have a significant effect on either the early cyclic AMP responses to the lectins or the responses to epinephrine or prostaglandin E (41). These observations suggest that colchicine may effect a specific stage of lymphocyte activation which results in augmentation and prolongation of a cyclic AMP response. It is therefore possible that colchicine might also effect the catabolism of cyclic AMP in mast cells differently than in the other lung cell types. Preliminary studies employing purified rat peritoneal mast cells has failed to support this possibility, but additional studies employing purified lung mast cells are required for certainty.

The association between the capacity of cyclic nucleotides to influence both the immunologic release of mediators and the inhibitory ability of colchicine suggests the possibility that these events may be related. It has similarly been suggested that cyclic nucleotides have dual effects on microtubules and secretory reactions involving the human nuetrophil $(39,42)$ and basophil (9). To be certain that these events are indeed causally related to one another, electron microscope analysis of microtubular integrity is necessary. Although this has thus far proven impossible in intact lung fragments, such evidence has been sought employing the neutrophil. Increased levels of cyclic GMP have been associated with increased numbers of microtubules $(38,40)$ while increased cyclic AMP levels correlate with diminished numbers of recognizable microtubules (39). Therefore, it seems possible that the modulating influences of increased levels of cyclic nucleotides upon the immunologic release of mediators from lung mast cells may also be induced through effects on microtubular assembly. Although it is reasonable to suggest this association, the functional criteria employed in the present study do not distinguish between independent and related events and the association between these phenomena may represent the summation of separate events.

The mechanisms by which cyclic nucleotides might influence microtubules are uncertain, although cyclic AMP is known to initiate phosphorylation of microtubules (23-26) or a closely associated protein (43). If cyclic AMP induces microtubular phosphorylation, it is possible that cyclic GMP acts through dephosphorylation. Indeed, such a cyclic GMP-related phosphoprotein phosphatase has recently been described (44).

The sequence of biochemical events involved in the immunologic secretion of histamine and SRS-A from human lung tissue has been partially elucidated (1). The inhibitory capacity of increased levels of cyclic AMP follows a calcium-requiring step which is suppressed by EDTA. EDTA at concentrations capable of preventing the immunologic release of mediators $(1,45)$ did not promote the inhibitory actions of colchicine and in fact may have diminished them. Thus, EDTA does not induce microtubular disassembly and may even favor polymerization as has been noted in other systems (46). The recognized intracellular events in the secretory pathway which are influenced by cyclic AMP and EDTA are therefore distinctly separated from each other. Thus, the postulated sequence of events involved in the release of mediators from human lung may proceed as follows (Fig. 5): The 


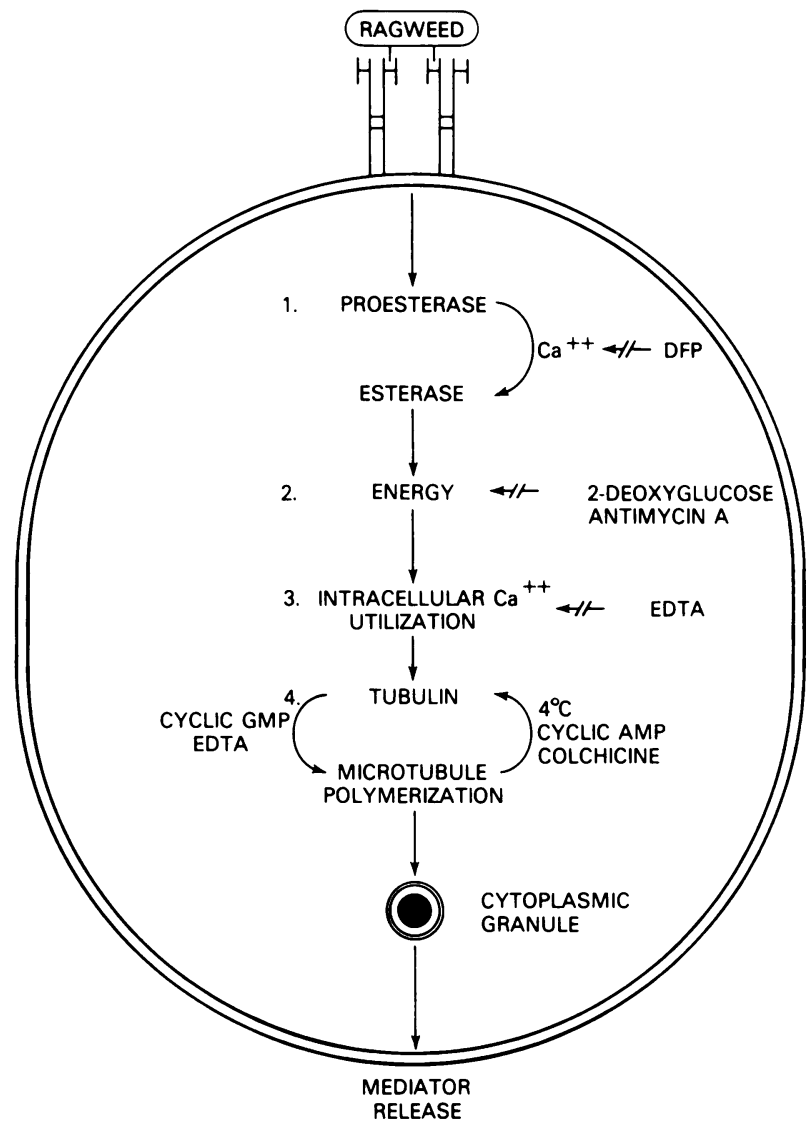

FIGURE 5 Schematic representation of the sequence of events involved in the immunologic release of histamine and SRS-A from human lung tissue.

bridging of two adjacent IgE molecules on the mast cell initiates activation of a serine esterase, energy utilization, and calcium movement leading to a stage which is influenced by the levels of cyclic nucleotides. Based upon the modulating influences that cyclic AMP and cyclic GMP exert on the functional state of assembly of microtubules, it seems possible that the requirement for polymerized microtubules in the IgEmediated secretory reaction in mast cells occurs at this stage and is followed by granular relocation along a microtubular framework.

\section{REFERENCES}

1. Kaliner, M., and K. F. Austen. 1973. A sequence of biochemical events in the antigen-induced release of chemical mediators from sensitized human lung tissue. J. Exp. Med. 138: 1077-1094.

2. Rohlich, P., P. Anderson, and B. Uvnas. 1971. Mast cell degranulation as a process of sequential exocytosis. Acta Biol. Acad. Sci. Hung. 22: 197-213.

3. Lacy, P. E., S. L. Howell, D. A. Young, and C. J. Fink. 1968. New hypothesis of insulin secretion. Nature (Lond.). 219: 1177-1179.
4. Williams, J. A., and J. Wolff. 1970. Possible role of microtubules in thyroid secretion. Proc. Natl. Acad. Sci. U. S. A. 67: 1901-1908.

5. Poisner, A. M., and J. Bernstein. 1971. A possible role of microtubules in catecholamine release from the adrenal medula: effect of colchicine, vinca alkaloids and deuterium oxide. J. Pharmacol. Exp. Ther. 177: 102-108.

6. Gillespie, E., R. J. Levine, and S. E. Malawista. 1968. Histamine release from rat peritoneal mast cells: inhibition by colchicine and potentiation by deuterium oxide. J. Pharmacol. Exp. Ther. 164: 158-165.

7. Levy, D. A., and J. A. Carlton. 1969. The influence of temperature on the inhibition by colchicine of allergic histamine release. Proc. Soc. Exp. Biol. Med. 130; 1333-1336.

8. Gillespie, E., and L. M. Lichtenstein. 1972. Histamine release from human leukocytes. Studies with deuterium oxide, colchicine and cytochalasin B. J. Clin. Invest. 51: 2941-2947.

9. Orange, R. P. 1974. The formation and release of slow reacting substance of anaphylaxis in human lung tissue. Prog. Immunol. 4: 29-39.

10. Robison, G. A., R. W. Butcher, and E. W. Sutherland 1971. In Cyclic AMP. Academic Press, Inc., New York. 91-142.

11. Orange, R. P., M. A. Kaliner, J. J. LaRaia, and K. F. Austen. 1971. Immunologic release of histamine and slow reacting substance of anaphylaxis from human lung. II. Influence of cellular levels of cyclic AMP. Fed. Proc. 30: 1725-1729.

12. Kaliner, M., S. I. Wassermann, and K. F. Austen. 1973. Immunologic release of chemical mediators from human nasal polyps. N. Engl. J. Med. 289: 277-281.

13. Lichtenstein, L. M., and S. Margolis. 1968. Histamine release in vitro: inhibition by catecholamines and methylxanthines. Science (Wash. D. C.). 161: 902-903.

14. Kaliner, M., and K. F. Austen. 1974. Cyclic nucleotides and modulation of effector systems of inflammation. Biochem. Pharmacol. 23: 763-771.

15. Bourne, H. R., L. M. Lichtenstein, K. L. Melmon, C. W. Henney, Y. Weinstein, and G. M. Shearer. 1974. Modulation of inflammation and immunity by cyclic AMP. Science (Wash. D. C.). 194: 19-28.

16. Kaliner, M., R. P. Orange, and K. F. Austen. 1972. Immunologic release of histamine and slow reacting substance of anaphylaxis from human lung. IV. Enhancement by cholinergic and alpha adrenergic stimulation. J. Exp. Med. 136: 556-567.

17. Kaliner, M. 1977. Human lung tissue and anaphylaxis. I. The role of cyclic GMP as a modulator of the immunologically-induced secretory process. J. Allergy Clin. Immunol. In press.

18. Kaliner, M., and K. F. Austen. 1974. Humoral control of the immunologic release of histamine and slow reacting substance of anaphylaxis from human lung. In Cyclic AMP, Immune Responses and Tumor Growth. W. Braun, L. M. Lichtenstein, and C. W. Parker, ediSpringer-Verlag KG., Berlin. 163-175.

19. Roisen, F. J., R. A. Murphy, M. E. Pichichero, and W. G. Braden. 1972. Cyclic adenosine monophosphate stimulation of axonal formation. Science (Wash. D. C.). 175: 73-74.

20. Porter, K. R., T. T. Puck, A. W. Hsie, and D. Keely. 1974. An electron microscope study of the effects of dibutyryl cyclic AMP on chinese hampster ovary cells. Cell. 2: 145-162.

21. Simantov, R., U. Rutishauser, and L. Sachs. 1975. Reversible inhibition of cAMP-induced axon formation in neuro- 
blastoma cells by concanavalin A and vinblastine. Exp. Cell Res. 95: 327-332.

22. Willingham, M. C., and I. Pastan. 1975. Cyclic AMP and cell morphology in cultured fibroblasts - effects on cell shape, microfilament and microtubule distribution and orientation to substration. J. Cell Biol. 67: 146-159.

23. Goodman, D. B. P., H. Rasmussen, F. DiBella, and C. E. Guthrow, Jr. 1970. Cyclic adenosine 3':5'-monophosphate-stimulated phosphorylation of isolated microtuble subunits. Proc. Natl. Acad. Sci. U. S. A. 67: 652-659.

24. Lagnado, J. R., C. A. Lyons, M. Weller, and O. Phillipson. 1972. The possible significance of adenosine $3^{\prime}: 5^{\prime}$-cyclic monophosphate-stimulated protein kinase activity associated with purified microtubular protein preparations from mammalian brain. Biochem. J. 128: 95.

25. Sloboda, R. P., S. A. Rudolph, J. L. Rosenbaum, and P. Greengard. 1975. Cyclic AMP-dependent endogenous phosphorylation of a microtubule-associated protein. Proc. Natl. Acad. Sci. U. S. A. 72: 177-181.

26. Soiffer, D. 1975. Enzymatic activity in tubulin preparations: cyclic AMP dependent protein kinase activity of brain microtubular protein. J. Neurochem. 24: 21-33.

27. Wilson, L., and M. Friedkin. 1966. The biochemical events of mitosis. I. Synthesis and properties of colchicine labeled with tritium in its acetyl moiety. Biochem. J. 5: 2463.

28. Stechschulte, D. J., K. F. Austen, and K. J. Block. 1967. Antibodies involved in the antigen-induced release of slow reacting substance of anaphylaxis (SRS-A) in the guinea pig and rat. J. Exp. Med. 125: 127-147.

29. Lowry, O. H., N. J. Rosenbrough, A. L. Farr, and R. J. Randall, 1951. Protein measurement with the Folin phenol reagent. J. Biol. Chem. 193: 265-275.

30. Gilman, A. G. 1970. A protein binding assay for adenosine 3',5'-cyclic monophosphate. Proc. Natl. Acad.Sci. U.S. A. 67: 305-312.

31. Olmsted, J. B., and G. G. Borisy. 1973. Microtubules. Annu. Rev. Biochem. 42: 507-540.

32. Imorie, S. 1952. The effect of colchicine on the microscopic and submicroscopic structure of the mitotic spindle. Exp. Cell Res. 2(Suppl.): 305-318.

33. Kaliner, M., R. P. Orange, W. J. Koopman, K. F. Austen, and P. J. LaRaia. 1971. Cyclic adenosine 3',5'-monophosphate in human lung. Biochim. Biophys. Acta. 252: 160-164.

34. Wilson, L. 1975. Action of drugs on microtubules. Life Sci. 17: 303-309.

35. Lagunoff, D., and E. Y. Chi. 1976. Effect of colchicine on rat mast cells. J. Cell Biol. 71: 182-195.
36. Wilson, L., K. Anderson, L. Grisham, and D. Chin. 1975. Biochemical mechanisms of action of microtubule inhibitors. In Microtubules and Microtubule Inhibitors. M. Borgers, and M. DeBrabander, editors. North-Holland Publishing Co., Amsterdam. 103-113.

37. Deysson, G. 1975. Microtubules and antimitotic substances. In Microtubules and Microtubule Inhibitors. M. Borgers, and M. DeBrabander, editors. North-Holland Publishing Co., Amsterdam. 427-451.

38. Oliver, J. M., and R. B. Zurier. 1976. Correction of characteristic abnormalities of microtubule function and granular morphology in Chediak-Higashi syndrome with cholinergic agonists. J. Clin. Invest. 57: 1239-1247.

39. Weissmann, G., I. Goldstein, S. Hoffstein, and P. K. Tsung. 1975. Reciprocal effects of cAMP and cGMP on microtubule-dependent release of lysosomal enzymes. Ann. N. Y. Acad. Sci. 253: 750-762.

40. Boxer, L. A., A. M. Watanabe, M. Rister, H. R. Besch, Jr., J. Allen, and R. L. Baehner. 1976. Correction of leukocyte function in Chediak-Higashi syndrome by ascorbate. N. Engl. J. Med. 295: 1041-1045.

41. Greene, W. C., C. M. Parker, and C. W. Parker. 1976. Colchicine-sensitive structures and lymphocyte activation. J. Immunol. 117: 1015-1022.

42. Zurier, R. B., G. Weissman, S. Hoffstein, and H. H. Tai. 1974. Mechanism of lysosomal enzyme release from human leukocyte. II. Effects of cAMP and cGMP, autonomic agonists and agents which effect microtubule function. J. Clin. Invest. 53: 297-309.

43. Rappaport, L., J. F. Leterrier, A. Virion, and J. Nunez. 1976. Phosphorylation of microtubule-associated proteins. Eur. J. Biochem. 62: 539-546.

44. Sandoval, I. V., and P. Cuatrecasas. 1976. Opposing effects of cyclic AMP and cyclic GMP on protein phosphorylation in tubulin preparations. Nat. New Biol. 262: 511514.

45. Orange, R. P., M. Kaliner, and K. F. Austen. 1971. The immunological release of histamine and slow reacting subtance of anaphylaxis from human lung. III. Biochemical control mechanisms involved in the immunologic release of chemical mediators. In Biochemistry of Acute Allergic Reactions, Second International Symposium. K. F. Austen, and E. Becker, editors. Blackwell Scientific Publications Ltd., Oxford. 189-204.

46. Weisenberg, R. C., and S. N. Timasheff. 1970. Aggregation of microtubule subunit protein: the effects of divalent cations, colchicine and vinblastine. Biochemistry. 9: 4110-4118. 